\title{
Opening the word hoard
}

\section{Four poems and two stories}

Edited by Gillie Bolton University of Sheffield

When the captain "opened his word hoard" in Beowulf, all he did was speak. ${ }^{1}$ We unthinkingly use words every day of our lives, yet through them we journey across time and distance, we are invited into the depths of mystery, and we can place our inmost thoughts before the gaze of others.

Fiction can offer graspable, comprehensible dynamic experience. We (particularly clinicians) understand and learn about others' lives in story form: patients bring narratives, clinicians create them, and help patients rewrite theirs. But life-as-it-is-lived does not happen in recognisable story form; it is confused, unfinished, and often with no satisfactory beginning. Stories are constructed out of experience, often over beer or coffee. Writers of literature create even more satisfying accounts than these.

Poetry offers concise and precise insight, using tropes such as metaphor in a way which no other written or oral form can. Fiction creates satisfying plot structure, rounded characters, effective description; it can leap over boring bits, tackle issues head on, convey multiple viewpoints, sidestep confidentiality problems, and offer readers the complexity of ambiguity: making them reach their own conclusions.

Fiction and poetry can offer reflections upon life. Characters, events and places must be taken seriously on many different levels, but not literally. Ted Hughes's Birthday Letters offers in-depth insight into suicidal depression: but it is a poetry collection not a case study. ${ }^{2}$ Camus's La Peste (The Plague) is an excellent course text. ${ }^{3}$ But it can be read clearly as allegory, fable even: Dr Rieux would not work as a role model.

Literature is an essential study for medicine. It deepens the awareness of issues and of experiences one cannot, or will never, have. It offers first rate material for ethical study (ethical dilemmas often make a plot fizz). An understanding of narrative can help clinicians develop a dynamic relationship with everyday complex stories of medical situations Reading and writing literature raises the awareness of all clinicians.

Through this regular section of the journal, we invite you to open the word hoards of your colleagues' writing, as well as to contribute your own.

Spirituality, or whatever word we can use which does not make everybody cringe, is undercelebrated in medicine. It has taken over from sex as the no-go subject in our culture. Stewart Mercer boldly and sensitively lets us in on his own experience, in First Operation.

Rebecca Ship uses a startling and shocking image to help us understand self harm and disability. Having read her Dracula, you'll never feel the same way again about self-harm, or Bram Stoker's popular villain.

David Hart, in The Real Surreal, opens the door of the psychiatric ward and invites us in: humorously and humanely. He tells us about it himself:

“These poems are my own but couldn't have been written had I not spent many hours in an acute adult psychiatric ward. They came out of my wilfully and willy-nilly identifying with patienthood, and by not writing anything that wasn't real to me. The ward oppressed me as it seemed to oppress others, hence In the Bunker. A woman walked around in a blanket and I wrote In My Blanket beginning, as I did for a number of other poems, with the little, hugely consequential word, "If"".

The phrase, The calorific value of the dictionary came from a patient in a conversation. It is dedicated, with his permission, to Ian. One can "write it straight" and one can find images, metaphors, projections; and it struck me one day that the best way was through the surreal: what else? Hence The Ward Now Coming into Land. I've opened a small window on one acute ward, that's all. The surreal surely has much more to offer yet."

\section{References}

1 Heaney S. Beowolf: a new translation. London: Faber, 1999:10. 2 Camus A. The Plague (La Peste). London: Penguin.

3 Hughes T. Birthday Letters. London: Faber, 1998.

\section{The real surreal}

In the bunker Inside the concrete bunker

there is a glasshouse, in the glasshouse we walk through treacle and back through it and sideways through it and we fly through it and crawl in it and we hop, skip and jump in it until the tea trolley comes 
and we have a tea trolley party, a cup of tea in the treacle party, and then we walk through treacle again inside the glasshouse

inside the concrete bunker.

\section{In my blanket}

If I walk around in my blanket I won't really have left my bed, if I walk around in my dreaming tent I'll manage, being half awake and protected. If I walk around in my blanket the world won't open right up, it won't ambush me with its full light, I'm awake but still in dark's lap.

Half way there is as much as I can bear, not too much world and all that shit, so I come half way to what's there,

I walk around in my warm blanket.

\section{The calorific value of the dictionary}

(for Ian)

Extant will make you fat if you are lackadaisical, but keep your raw material in good nick and genial will be yours, my friend, laden

of a rainbow kind

will medium you into a forward roll, $\mathrm{O}$ yes, and further

into scarper, fearlessly, for frolic and freeflow.

Tales tell of thrillers stuck in the ophidian throat so that nothing would come out

except moulding commotion,

which made a person thin with silence, $\mathrm{O}$ yes, and more,

paralysis, and no amount of patter

in the inner self

would free them. Psychoacoustic exercise, now, take that on,

not up blind alleys or in the meta-language of toxicity,

go for the tie-break and, $\mathrm{O}$ yes, beyond that,

into sanguine, into proceeding and on into pullulation,

that'll get the fat off

and let the sunshine do its damndest

to make you happy.

\section{The ward now coming into land}

The ward now coming slantwise into land is running twelve melons early, anyone meeting this ward is advised it is very juicy and may slide off the runway into the bog seven miles away, where the mermaids are still struggling to get out of the story.

Regulations say

a juicy ward landing without permission has to lose its tea trolley as ballast and take off again, unless the mermaids are staying and singing their fruit bowl song. Please await further announcements. David Hart

\section{First Operation}

When it happened it came as a shock. The scalpel parted the yellow war-painted flesh, from sternum to pubis, a second stroke the fat, a third the final film; the membranous peritoneum.

The person beneath my hands was no longer a person, but a collection of organs, bathed in warm red water framed in a canvas of green. At the nod of the surgeon I held back the guts, retracted the liver, noticing the colours and textures, contrasting the warmth of the deep with the cooling peripheries, tasting the smell of cauterised veins. Then, the strange excitement at seeing the cause; a big hole in the aorta.

Yet my response was one of disbelief. It was a shock. Of course I'd known the anatomy for years, seen it all in the dissecting room; liver, kidneys, spleen, guts. But in life, somehow I'd expected more, something else. I'd expected to see the vital source, the soul, the thing we really are. It was childish, naïve, but I was truly disappointed. "Is this all?" I wondered, knowing in my heart that it wasn't.

My scientific mind however, sought proof. I wanted to ask the surgeon: "Excuse me for asking, but where has the soul gone?" or the anaesthetist: "Do you store it in one of these machines?" Perhaps I could whisper into the ear of the staff nurse : "Excuse me, where do you put the soul?" It was a tutorial we never received.

Two weeks later I got my answer. Mrs Green had recovered and we had a delightful chat. She told me her life story, her marriage, her children, her hopes and her fears. She was eighty but had the spirit of a child and the grace of God in her countenance, in whose hands she firmly placed her trust. She told me all this is in an open, strong, gentle, confident voice. This woman's Soul was palpable. It shone in her eyes and sang in her voice, in her humility and in her wisdom. It invited me to see.

So where was it then, when she teetered on the brink? I cast my mind back. I'd been afraid, and in my fear I'd missed the clues. Slowly they came back. The nurse who'd stuck out her tongue behind the surgeon's back, and winked at me as he'd barked another command. The other medical student who'd prodded me playfully in the ribs after a painful silence had surrounded a machine-gun round of questions that neither of us could answer. The porter, who at the end patted me on the back saying another job well done. Making me feel as if I'd done the operation myself. Yes, there were clues, signs, pointers that I'd missed.

The soul exists to touch the hearts of others as they toil. It does so unassumingly, anonymously, silently, seeking neither reward nor recognition, only entrance, permission, a conscious home. Mrs Green gave me a second chance and showed me how to open the door. Stewart W Mercer 


\section{Dracula}

Dracula was moonlighting as a phlebotomist. $\mathrm{He}$ reflected on the irony of this as he ventured out into the daylight. He had been so lonely and now he had a chance to make new friends. He had a thick accent, which repulsed people. He wasn't very popular with the few other Transylvanian exiles he had met since his arrival. They thought him strange and difficult. They didn't realise that his somewhat brusque manner was more to do with his physical discomfort than any desire on his part to rebuff them. The light was a problem. His skin chafed and burned and he broke out in a dreadful rash. He had trouble with his eyes. So he went to his GP, who prescribed a steroid skin cream and some eye drops.

Everything went well at first. $\mathrm{He}$ was skilled at taking blood, and the sight of it made him feel warm inside. But then things began to go wrong. The proximity to his staple diet excited him. His hand would shake as he felt the slight give when sliding the needle into a patient's vein, and his heart would start pounding as he watched the tube fill with the wonderful dark red liquid. He managed to control himself, however, by repeating over and over to himself "Concentrate...concentrate". $\mathrm{He}$ would have preferred old fashioned syringes-that way, he could have saved a little bit from each procedure. This new-fangled method meant that all the blood went straight into the bottle. Altogether cleaner and safer, he acknowledged ruefully, mindful of infection control, but frustrating all the same. Still, he did not want to be dishonest. He supposed pinching blood was like pinching paper-clips. On the other hand, blood didn't come under the heading of office supplies. Oh, well, he couldn't change the system, so he told himself to be thankful for what he did have-a job, contact with his favourite substance and, while he sometimes ached for the witty repartee he indulged in so naturally back home, he had lots of new people to talk to.

Later, he could have kicked himself for letting it all go in one stupid, self-indulgent moment. Perhaps it was because he had a headache that day and wasn't thinking clearly. He had had a bad night-indigestion from fresh frozen plasma that wasn't fresh at all, damn that supplier. The summer sun still managed to bore its way through his dark glasses and make his eyes water. He had smothered himself in sun block as well.

What happened was so silly. The patient was a very pleasant young woman, very attractive, actually, with creamy skin and a light dusting of freckles on her arm. She rolled up the sleeve of her jumper and there it was-a slight swelling, a hint of blue. He felt something roll over in his chest. $\mathrm{He}$ tightened the tourniquet and gently probed the crease of her elbow with his finger. She smelled faintly of tea roses. He allowed the fine edge of the needle to hover within a millimetre of her skin and then gently, oh so gently, he applied just enough pressure for the point to pop the surface and find its way into the vein. There was a slight hiss as a thin jet of blood shot into the tube (or was that the sound that almost whistled through his teeth as he whispered "lovely"?). He loosened the tourniquet and then, and then-oh, God, he couldn't resist it. As he withdrew the needle a large drop of blood oozed out. It swelled into a deep purple globe and trembled, as if it couldn't decide what to do, and then it rolled, becoming a thin trickle which slid across the woman's soft, almost translucent skin. He was transfixed by the sight of that delicate ruby thread teasing its way down her luminous, bluetinted forearm. Then everything happened in a flash. In an almost courtly gesture, he held her wrist between his thumb and index finger, cupped her elbow with his other hand, brought her arm up to his lips and licked the trickle of blood all the way back up to its origin where he planted a gentle kiss. Strangely, she didn't jerk her arm away or scream. There was a moment of utter stillness while they locked eyes. She stared at him, at his tongue as it finished its journey across his lips, then she slowly stood up-at arm's length, he remembered later, with bitter humour-leaned over him, picked up a wad of cotton wool from his trolley and pressed it to her elbow. She then left. He thought of saying sorry, but somehow he knew that wouldn't be enough. It wouldn't explain. And, anyway, he was still savouring the familiar but thrilling taste of her blood. Odd that it was always the same, no matter who it came from. You would think a woman's blood would perhaps be a little sweeter than most, lighter, fruitier. A labourer's blood should have a kind of gamy tang to it, he mused. And a child...well, he had sampled babies and toddlers, sullen, acne-riddled teenagers and pubescent clubbers and he was struck by the consistency with which that metallic acridness hit his taste buds. The only difference he could detect was between fresh and stored blood. Rather like tinned and fresh salmon-the former palatable but lacking something-a quality of texture, perhaps.

Well, he had certainly messed things up now. Damn and blast, he muttered as he hurriedly ripped from the notice-board the postcards of the forests and mountains of his native country that he had pinned there. Not for the first time would he have to pack up and leave without saying goodbye to anyone. He slipped out of the surgery unseen. When he got back to his flat, he pulled the curtains and sat in the dark. It was cooler now, and his skin didn't feel quite so fiery. But his thoughts bounced around the inside of his skull like a pinball.

He tried to remember what that counsellor had said to him about allowing himself to be vulnerable. His father, on the other hand, aware that his son's passage through life was bound, like his own, to be a hard one, had taught him the value of self reliance. Letting others see your weakness was to cast yourself adrift in a harsh, unyielding world where people didn't care about you and would just as soon betray you, given half a chance. Remember, he said, you'll have no one but yourself to fall back on. Well, father, he thought, for once you were right, and he laughed, a joyless, hollow laugh that died there in the room. 
$\mathrm{He}$ stood up, walked to the kitchen and rummaged around in the cutlery drawer. When he had found what he needed he picked up one of the mugs stacked on the draining board, emptied the dregs of that morning's tea into the sink and rinsed out the mug. He came back into the sitting room and sat down, placing the mug and a serrated bread knife on the table in front of him. For a long time he didn't move. Then, in a seamlessly quick and surprisingly delicate movement, he picked up the bread knife and drew the blade forcefully across his forearm. He shuddered as he watched the blood drip freely into the mug. His scalp prickled as he once again sliced at his arm, and again, and again With each cut he winced but after a while he felt nothing but a kind of anticipatory calm and a deep sense of resignation. When the mug was half full he sniffed deeply from it, threw his head back and allowed the sticky liquid to fill his mouth and slide down his throat. He gulped greedily. It was warm and thick and glutinous. With each swallow he grew dizzy. He felt red, amoeba-like fingers reaching into every crevice of his body, squeezing their way into all his secret places, filling him up. God, it felt good. $\mathrm{He}$ ran his tongue over his teeth, which was coated with bits of clotted blood. He began to drift into sleep ..... nothing was as satisfying as this, not even sex. He giggled. Far less complicated than sex. You could dispense with the foreplay. No explaining, no negotiating, no compromises. Just you and the luscious, explosive abundance of your own liquid essence.

Rebecca Ship

David Hart has been Poet in Residence for the South Birmingham Mental Health NHS Trust, a day a week for a year. Stewart $W$ Mercer is a General Practitioner and Research Fellow, Department of General Practice, University of Glasgow Rebecca Ship is a GP in Bradford. Gillie Bolton, Editor of Opening the word hoard, is Writer and Research Fellow in Medical Humanities, University of Sheffield Institute of General Practice and Primary Care, Community Sciences Centre, Northern General Hospital, Sheffield S5 7AU. email: g.bolton@sheffield.ac.uk 